\title{
Ghana's Progress
}

\author{
E. O. A. Asibey
}

In Ghana wildlife is valued especially as a source of meat. But overhunting has led to serious depletion of nearly all game species, in some cases almost to the point of extermination. However, the Government is now concerned that the country's wildlife should be conserved and used on a sustained yield basis, and recently new national parks have been created, existing reserves enlarged and government spending on wildlife substantially increased. The author, who is head of the Wildlife Department and FPS correspondent in Ghana, describes the difficulties of making conservation effective in a country where ignorance about wildlife, other than its value for the pot, is the rule.

Wildlife has always been recognised in Ghana as a natural resource and a source of protein. At the traditional courts, wildlife protection was the duty of all citizens in general and court pages in particular. The tax on all big game killed was a hind leg. Hunting was a respectable profession. There were no special reserves, though lion, leopard and elephant were and still are 'royal game'. Skins of these animals and special parts were the chief's property and failure to surrender them met with severe punishment. Traditional conservation measures were enforced for small animals by what amounted to close seasons, but today they are largely disregarded, especially by the town-dwelling 'week-end hunters' who account for an increasing proportion of commercial hunting. Although 1901 saw the beginning of legal protection and game reserves were constituted in 1909, the wildlife has suffered increasing overexploitation, leading to the eradication of species in various localities (6), (4), (2), and the virtual extermination of at least two, the manatee and the pygmy hippo. A Game Department was created in April 1965, and given full legal status within the Ministry of Forestry at the end of 1967, after oscillating between the Ministries of Agriculture, Animal Husbandry, and Parks and Gardens. Today it is within the Ministry of Lands and Mineral Resources (including forestry and wildlife).

But wildlife conservation has been inhibited by lack of funds and personnel to administer the law, the use of wild life as a source of food, and public ignorance.

\section{General Action}

Between 1901 and 1965, except for 1949-52, wildlife conservation was an appendage of departments already fully committed. Forced by circumstances to give it very low priority, at times amounting to gross negligence, they created an impression of government indifference both before and after Independence.

Laws were promulgated without funds or people to administer them. In 1911, large game reserves were created on the Afram plains, but were not wardened and are worse than useless for the purpose they are 
supposed to serve (12). The same author urged that, 'personnel is essential to create either an independent Game Department, or to be incorporated in some other department which would preferably be the Forestry', but nothing was done until 1949, when a Game Warden was appointed to head a Game Department. But with inadequate funds and no clear policy nothing was achieved, and in 1952 wildlife conservation became the appendage of the Tsetse Control Department (whose primary object was the "elimination and control of game associated with human and animal try. panosomiasis'), and in

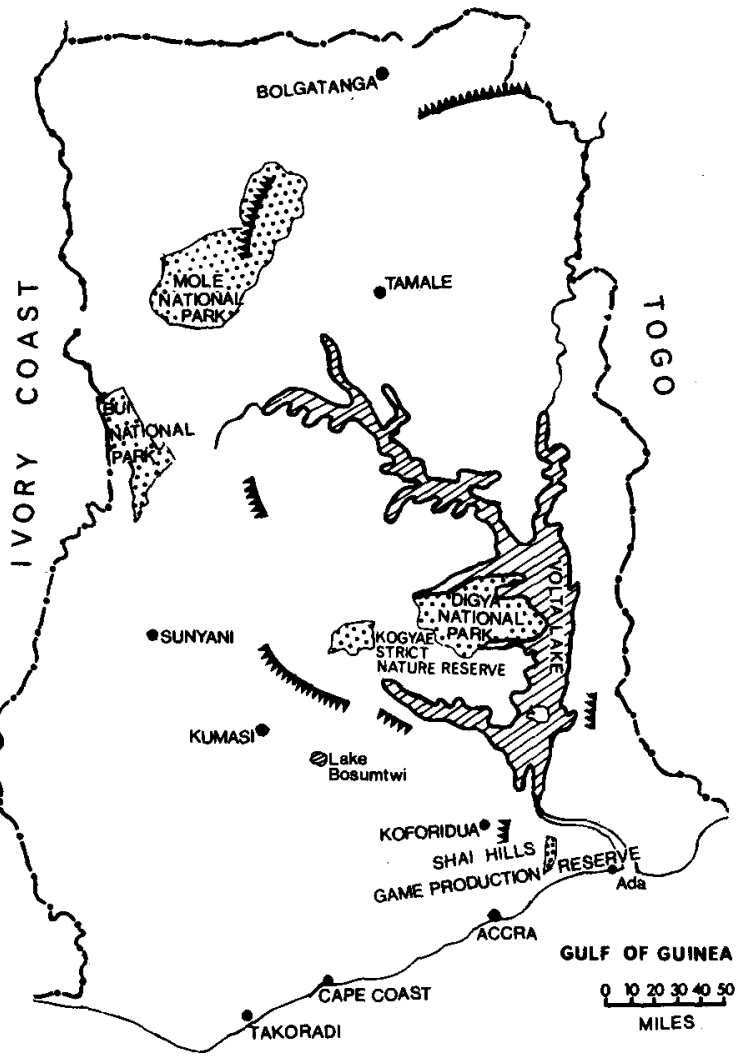

1957 to the already overloaded Forestry Department. However, although there is still no accepted written wildlife policy for Ghana, the present Department owes its existence to the Forestry Department's efforts. In April 1965, the present Department was established de facto within the Ministry of Animal Husbandry as the Department of Wildlife Preservation, legally established two years later, and given funds; reasonable posts were created to allow recruitment of staff, who, however, had to carry out undefined functions other than the Wild Animals Preservation Act (8). Though it is difficult to get both unskilled labour that is committed to conservation and the senior and middle grade skilled officers who can instil keenness and interest, wildlife conservation may today be said to be receiving high governmental concern.

\section{Staff}

Wildlife conservation as a career is largely unknown in Ghana. Conditions of service are the same as those for professions such as agriculture, and forestry, which, however, prove more attractive. Thanks to help from WWF, the FPS/WWF Revolving Fund, African Leadership Foundation, A. Lang Ltd, (Ghana), a group of ladies in Kumasi, one lady from Kenya and another from Hawaii, eight Ghanaians are training in Tanzania's College of African Wildlife Management, three doing the diploma course and five the certificate course. FAO experts have helped to establish a permanent pre-entry training course for recruits into the lower and middle grade technical 
units at the Mole Game Reserve. This scheme also offers refresher courses for serving officers. One senior officer has completed a year's attachment at Mweka under the FAO scheme and two senior officers have attended the international short course in national park management in America under American Cultural Affairs sponsorship. The British Government is sponsoring the post-graduate training of one senior officer at Aberdeen University, and visiting scientists and expedition teams, particularly from the United Kingdom, have helped in training as well as instilling interest in junior technical staff. These aids are gratefully acknowledged. The staffing and training position are improving rapidly and the future seems much brighter than ever before.

The law enforcement position is quite critical. The police are as ignorant of the game laws and the animals protected as the public itself, and the Department's small staff is completely unable to enforce the game laws effectively throughout the country. Honorary wardenship has been found equally ineffective. Throughout the close season, all markets have bushmeat for sale, both live animals and carcasses of fully protected species, and courts have proved sympathetic with the culprits.

There are plans to get police officers to help with the training in the Mole Game Reserve, for supplying police with pictures of protected animals, and for the Department to help the police more effectively in enforcing the protection laws. The foundations have been laid for an effective countrywide programme embodying all the functions of East African national parks and game departments, and the conservation education in environmental conservation to be found in the United Kingdom and the USA. Encouraging progress has been made in stimulating interest and co-operation in all walks of life.

'A hungry man is an angry man'. Ghana's livestock herds have always been too small to meet the demand for meat, and the main source of supply is imported livestock supplemented by hunting, particularly in the rural areas. The human population is increasing. The various forms of meat supply are complementary and the development of any one cannot compensate for loss of the others, so the Department of Game and Wildlife must regard the wildlife as a crop to be managed and harvested. The Department has established that the meat of most animals killed in the rural areas finds its way to the commercial centres, passing through at least three hands before it reaches the consumer at a very high price. Although the most expensive meat on the market, the demand exceeds the supply, and the meat of any animal finds a ready market (5). Thus any reasonable scheme for bushmeat production should be able to pay its way.

Wildlife, especially birds and mammals, is also exported live, and this is a growing trade. Dealers have even written asking the Department to collect for them. The traditional trapping method for mammals is the cruel and wasteful one of killing the adult in order to capture the young, and so far there is no law to prevent it. Another form of trade is in skins. This hits crocodile, monitor lizard and colobus monkey as well as the cats - both big cats, like lion and the now very rare leopard, and the smaller ones like genet. 
For the first time information is being collected to enable effective steps to be taken to ensure a sustained trade rather than kill the goose that lays the golden eggs. The Government favours the establishment of game production reserves, but the scheme has been held up by staffing problems. There is also a need for a wildlife utilisation officer to review uses, capture techniques, trade, local and international prices and potential pests.

The Government has accepted the IUCN report (7) which recommends a wildlife restoration plan, but its success depends on the availability of funds and personnel. The Government has approved a scheme to recruit expatriate staff, and the British Government is encouraging able people to come to Ghana's aid through a salary supplementation scheme; one officer is already at work under the scheme. The Volta Research Project in collaboration with FAO has engaged one expatriate officer to help the Department. Once the post of wildlife utilisation officer is created with the rank equivalent to that of game warden, a contract officer could be found to fill the post initially until a Ghanaian officer can be trained.

Having overhunted to the point of exterminating the animals, the people now say that 'the animals have become too clever' and thus too elusive to hunt, refusing to accept that they are no longer there, despite the lack of tracks, droppings, and grazing and browsing evidence. Experts argue that the small mammals, such as rodents and monkeys, now the bulk of the Department's bushmeat records, are so wily and breed so rapidly that they can be in no danger, but people in areas that have already lost all their wildlife sound a warning note. Both the hunting methods and the practice of ignoring the close season (August 1 to November 30) are serious factors. Education, indisputably the most valuable and effective tool for wildlife conservation, is urgently needed at all levels, but Ghana has to look outside for an education officer. Talks and slides shown in schools, colleges and the university, visits by schools, colleges and university parties to the Mole Game Reserve, with talks and slides to supplement guided tours, are proving effective. The soil in this field is very fertile indeed and any aid that would provide an officer for this assignment would be invaluable.

\section{Establishment of Reserves}

Protection for animals in large herds is obviously best achieved in reserves. Since 1909 a number of reserves have been legally established but without men or funds to look after them $(6,12)$. In 1960 some valuable reserves were unfortunately dereserved. One of these was dereserved because it was believed that the animals had been shot out (6), but an American soil survey team reported in 1962 that it was one of the best wildlife areas in Ghana (13). The closure of the Volta Dam, and the consequent lake formation, forced an animal rescue operation in 1964 which gave an opportunity for field work; this confirmed the 1962 American finding and the need to reinstate the area (3). The clock which was set back in 1960 is being reset. With the help of the Volta River Authority and FAO, an officer has been recruited to survey the area and produce plans for the re-establishment of the reserve on the 
shores of Lake Volta. The Mole Game Reserve has been established, demarcation is completed, and its size, coupled with its management and facilities, qualifies it for inclusion in the United Nations list of National Parks and Equivalent Reserves.

The urgent need is to consolidate the present reserves which have neither efficient protection nor study, and also to survey other wildlife areas of the country to find out whether the present reserves are adequate or whether it is essential to establish others for various uses including meat production. As yet there is no high forest area of significance under game reserve, although the fauna of this zone is of vital scientific and cultural significance and its economic potential is probably high.

\section{Conclusions}

The role of wildlife in Ghana's economy as an essential source of protein has long been established qualitatively, and recently also quantitatively, and an active small Department is feeling its way in tackling the enormous management problems. The Government has now firmly resolved to take effective measures to conserve a sustained wildlife resource in Ghana, and the restoration programme is just beginning with the identification of the problems, of which the most serious are

(1) to find and train people at all levels for conservation work, and improve the conditions of service in order to keep them.

(2) to educate the public at all levels to understand that a new approach (conservation) will not only guarantee a regular take-off but also provide increased yield.

\section{Postscript}

Since this paper was written considerable progress has been made. The post of Conservation Education Officer has been created and effectively filled. There are two Canadian University Service Overseas workers and five Peace Corps workers at post, and we expect to have three more Peace Corps workers by June 1972. Three more Ghanaian graduates have been recruited, and a fourth officer is expected by December 1971. We now have six officers holding the Mweka College diploma, one of whom has been accepted by Nairobi University for a degree course, and two with the certificate. If aid can be found he will be released to undertake the degree course which would be most valuable for the Department's work in 1973. Three more officers are financed by the Ghana Government, one doing the diploma and two the certificate course at Mweka.

\section{Legislation}

In April 1971, the Wildlife Conservation Regulations 1971 (L.I.685) came into force. This greatly increases the list of animals under complete protection - including elephant, the big cats, crocodiles, and all coloboid monkeys - regulates the export of live animals and trophies, and rationalises hunting regulations and the issue of hunting licences to kill or capture. In August 1971, all game officers of the rank 
of game ranger and above were appointed public prosecutors. Another Legislative Instrument, which received Ministerial approval, and was in force by the end of 1971 , created three national parks, two of them completely new areas of 780 and 1200 square miles respectively, and the third a redesignation and enlargement of the existing Mole Game Reserve from 900 to 1800 square miles. Simultaneously two other existing reserves will be enlarged.

The recognition given by the Ghana Government to the importance of conservation and wildlife management is reflected in the funds made available. Money allocated for recurrent expenditure for 1971-72 increased by 59 per cent over 1968-69, development expenditure by 62 per cent, much of the latter being for the setting up of multiple use projects, with emphasis on wildlife as a source of protein.

There is now a mobile faunal survey unit which can be sent anywhere in Ghana to assess the potential of areas as future reserves or parks. This team has already produced valuable preliminary data on a possible high forest/elephant park, and is now investigating other areas.

\section{References}

1 ASIBEY, E. O. A. (1966): The case for wildlife conservation in Ghana, Ghana Farmer Vol. X, No. 2, pp. 66-72.

2 ASIBEY, E. O. A. (1969): Wild Animals and Ghana's Meat Supply. (Dept. of Game and Wildlife. Mimeographed. Distribution to the Ministries of Forestry and Economic Affairs, and members of the Committee on the Development of Meat from Wildlife.)

3 ASIBEY, E. O. A. (1969): Wildlife in the Volta Basin pp.366-372 of Man-made Lakes. Ed. by Letitia E. Obeng. (Ghana Universities Press, Accra.)

4 CANSDALE, G. S. (1964): Report to the Government of Ghana on the establishment of Zoological Gardens and Wild life Conservation (FAO/EPTA Report No. 1800 43pp. Mimeographed.)

5 CLOTTEY, ST. JOHN A. (1968): Production and Utilisation of Animal Products in Ghana. (Food Research Institute: Special Report No. 1 in Animal Products. Mimeographed.)

6. COLLINS, W. B. (1961): Wildlife conservation in Ghana. African Wildlife Vo.15 No.3, pp.205-212; Vol.15 No.4, pp.280-287.

7 CURRY-LINDAHL, K. (1969) Report to the Government of Ghana on the Conservation Management and Utilisation of Ghana's Wildlife Resources. IUCN.

8 GHANA GOVERNMENT (1961): Wild Animals Preservation Act, 1961 (Act 43).

9 GHANA GOVERNMENT (1968): Economic Survey of Ghana.

10 GOLD COAST GOVERNMENT (1901): McCarthy, Cap. 203, Ordinance No. 2, 1901 .

11 GOLD COAST GOVERNMENT (1951): Report on the Game Department for the year 1950-51.

12 HAYWOOD, COL. A. H. W. (1933): Reports of Special Mission to West Africa to inquire into the preservation of Wild Life, 1931-2. (Society for The Preservation of the Fauna of the Empire. Occasional Paper No. 2.)

13 SMITH, G. K. (1962): Report on Soil and Agricultural Survey of Sene-Obosum River Basin, East Brong Ahafo and Ashanti Regions, Ghana. (US Department of State, AID, Washington, DC.) 